SAD / JSR

Sosyoloji Araştırmaları Dergisi / Journal of Sociological Research

Özel Sayı (Nisan / April 2021) : (216-246)
Araştırma Makelesi / Research Article

Geliş Tarihi / Submited: 09.03.2020

Kabul Tarihi / Accepted: 22.06.2020

\title{
ÜREMEYE YARDIMCI TEKNOLOJİ YASAKLARINA KARŞILIK PRATIK-RASYONEL DAVRANIŞ
}

\section{Gülsevim EVSEL ${ }^{1}$}

\section{ÖZET}

Türkiye'de üremeye yardımcı teknolojiler (ÜYT) alanında, evli çiftlerin üreme süreçlerinde üçüncü kişilerin bedenleri ve üreme hücrelerinin kullanılması yasaktır ve bu yasağa uymayanlar birtakım yaptırımlarla cezalandırılmaktadır. Bu nedenle bu makale, Türkiye vatandaşlarının bu yasal yaptırımlardan ve toplumsal dışlanmalardan; yani her türlü cezadan kaçınmak için yasadışı yollara başvurmak ve Weber'in ifadesiyle pratik rasyonel davranış sergilemek durumunda kaldığını iddia etmekte ve bu iddiayı saha bulguları ile desteklemektedir. Bu çalışma, araştırmacının 2018 yılında taşıyıcı anneler, yumurta donörleri ve bu yollarla çocuk sahibi olan aileler ve embriyologlarla yüz yüze gerçekleştirdiği nitel görüşmelerden yola çıkarak, bireylerin çocuk sahibi olamamak veya çocuk sahibi olmak için başka bedenlere ihtiyaç duymaları konusunda yaşadıkları toplumsal baskıya ve/veya çevreleri tarafından küçük düşürülmeye karşı geliştirdikleri pratik-rasyonel yönelimlere odaklanmaktadır.

Anahtar Kelimeler: Pratik Rasyonel Davranış, Taşıyıcı Annelik, Yardımcı Üreme Teknolojileri, Yumurta Donasyonu.

${ }^{1}$ Dr. Öğr. Üyesi, Yüzüncü Y1l Üniversitesi Edebiyat Fakültesi, Sosyoloji Bölümü

$\begin{array}{ll}\text { SAD / JSR } & 216 \\ \text { Özel Sayı } & \end{array}$




\section{PRACTICAL RATIONAL BEHAVIOR IN RESTRICTED ASSISTED REPRODUCTIVE TECHNOLOGIES}

\section{ABSTRACT}

In Turkey, using the third parties' bodies and gametes in the In Vitro Fertilization processes of married couples is banned and punished via some regulations in the field of ARTs. For this reason, it is claimed and supported by the field results in this paper that Turkish citizens were forced to apply for some ways in order to avoid any kind of punishment such as social exclusion and legal enforcements. This study claims that Turkish citizens are forced to appeal to illegal ways in order to avoid any kind of punishment and are forced to enact in accordance with the practical rationality definition of Weber. This study focuses on practical rational behaviors developed against social pressure and/or humiliation of childless people's environment about not being able to have children or requiring other bodies in order to have children. This focus of the researcher is supported by qualitative interviews with surrogate mothers, oocyte donors, couples who had their children via these ways and embryologists in 2018.

Keywords: Assisted reproductive technologies, oocyte donation, practical-rationality, surrogacy 


\section{GİRIŞ}

Üreme tarihi insanlık tarihi ile paralel ve eşanlı bir şekilde yol almıştır, almaktadır. Öyle ki, önemini hiçbir dönem yitirmemiş hem bireysel hem toplumsal hem de siyasi yaşamla daima iç içe olmuştur. Üreme öncelikle nüfus artışı konusuna olan farklı yaklaşımı ile Malthus (1998, s. 32) tarafından ele alınmıştır. Bu yaklaşıma göre üreme, bireysel üreme yeteneğinden, toplulukta aile soyunun diğerlerinden daha baskın hale geldiği bir başka gücün göstergesi olmaya, ölümlerden daha fazla olması ve doğal kaynakları fazla tüketmesi durumunda nüfus için kıtlığa varan tehlikeler arz etmeye kadar büyük önem taşımaktadır (Malthus, 1998, s. 32). Modern toplumda ise üreme, Foucault'nun (2001, s. 137) "kapitalist toplum için bütün diğer şeylerden daha önemli olan bedensel olan, fiziksel olan, biyolojik olan biyopolitikadır. Beden biyopolitik bir gerçeklik; tıp ise biyopolitik bir stratejidir," ifadesinde görüleceği üzere, birey ve devletin bu yeni ilişki tanımı ile bir biyopolitika/biyoiktidar nesnesi olmaya kadar ileri gidecektir.

Bireylerin içerisinde yer aldıkları toplumlarda bir nevi saygınlıklarını tamamlayıcı bir unsur olan üreme, bazı bireylerde çeşitli sebeplerle doğal yollarla gerçekleşememektedir. Bu sebepler, kadınlarda rahim veya yumurtalıkların doğal yolla çocuk sahibi olmaya elverişli olamaması şeklinde olabileceği gibi, erkek bireylerde sperm sayısı, kalitesi veya cinsel aktiviteyi gerçekleştirecek yeterlilikte olamama şeklinde de kendini gösterebilmektedir. Bu iki durum dışında eşcinsel bireylerin çocuk sahibi olma istekleri de yine aynı cinsten oldukları için doğal yollar üzerinden sonuç getirmemektedir.

Evlat edinme, çocuk sahibi olamayan bireylerin başvurdukları bir çözüm yolu olarak kabul edilmektedir. $\mathrm{Bu}$ çözüm, tarihsel bir geçmişi ve süreç içindeki dönüşümünü beraberinde getirmiştir. Ungan Çalışkan (Metin'den aktaran Ungan Çalışkan, 2016, s. 494) çalışmasında, taşıyıcı anneliğin evlatlık müessesesiyle genellikle karıştırıldığını; ancak evlatlık durumunda annenin cinsi münasebeti sonucu ortaya çıkmış, doğmak üzere ya da doğmuş olan çocuk için en iyi çözümün bulunmaya çalışıldığını aktarmıştır. Oysa taşıyıcı annelikte henüz embriyo olarak dahi varlık göstermeyen müstakbel bir bebeğin akıbeti, ortada bir 
cinsel ilişki olmaksızın tayin edilmektedir; dolayısıyla taşıyıcı anneliğin yetişkin/ebeveyn odaklı; evlatlığın ise çocuk odaklı kurumlar olduğu söylenebilir (Kopfensteiner'den aktaran Ungan Çalışkan, 2016, s. 494).

Özbay'ın (1999) bu konuyu çalışmalarında daha çok tarihsel boyutu ile ilişkili olarak ele aldığı görülmektedir. Ona göre, evlilik çatısı altına alınan "diğer" çocuklara bu kurumda, kölelik, ev-içi hizmet, duygusal veya cinsel sömürü, ya da çocuğun kişisel gelişimine katk1 sunması gibi nedenlerle yer verildiği; hatta evlatlık kurumu ve kölelik kavramı karşılaştırıldığında, evin kız çocukları ile bu "diğer" çocukların arasında çok fark gözetilmeyebildiği görülmektedir (Özbay, 1999, s. 2). Ancak, bu çalışmanın bulgularında da yer verileceği gibi, bireyler çeşitli sosyal ve psikolojik nedenlerle evlatlık edinmekten ziyade, "kendi" çocukları olmasını daha çok arzu etmektedirler. Bu yeni teknolojinin dini ve yasal açılardan beraberinde getirdiği yasakları da bir şekilde bertaraf etmeye çalışmaktadırlar.

Modern tıp ve ÜYT’ler, çocuk sahibi olamayan bu çiftlere başka bireylerin bedenlerini kullanmak ve/veya bu üçüncü kişilerden üreme hücreleri sağlamak yoluyla çözüm sunabilmektedir. Ancak bu durumda, ÜYT’lere başvuran çiftin veya bu süreçlerde yer alan yani başkalarının çocuk sahibi olmasına bedeni ile yardımcı olan bireylerin bu durumu toplumsal çevrelerine açıklamaları ve/ veya bir şekilde bu süreçleri meşrulaştırma ihtiyaçları ortaya çıkmaktadır. Aile kurumunun toplumda üremeyi meşrulaştırıcı rolü olmasına rağmen; çocuk sahibi olmak için üremeye yardımcı teknolojilere başvuran bireyler, evli olsalar bile başvurdukları yöntem hukuken meşru kabul edilmediği için yine bu süreçlerde yer aldıklarını ve davranışlarını saklamaya ihtiyaç duymaktadırlar. Diğer bir deyişle, özne olarak beden ve kurum olarak onu çevreleyen aile, biyopolitikanın hedefi haline gelmiştir.

Türkiye' de yasal olmayan ve dinen de uygun görülmeyen, üçüncü kişilerden donasyon alma yoluyla çocuk sahibi olmak isteyen bireyler ve bu süreçlerde yer alan diğer kişiler genellikle, söz konusu eylemlerini gizli yapmak, saklamak, diğer bir deyişle içinde bulundukları topluluk tarafından dışlanmamak için rol yapmak durumunda kalmaktadırlar. Yargılanmaktan kaçınmak için tercih ettikleri bu davranışlar, bireylere çocuk 
sahibi olma süreçlerinde zaman kazandırma, tepki almaktan kaçınma, kendini koruma altına alma gibi kısa süreli yararlar sağlayabilmektedir. Ancak görülmektedir ki, bu kaçınma ve rol yapma davranışları, kişilerin kendilerini güvende hissetmediği, gayrı meşru ortamlar yaratmakta ya da bizzat bu ortamlarda gerçekleşmektedir. Bu makalenin araştırma sorusu ile ortaya konulmak istenen, bireylerin ÜYT'ler yoluyla çocuk sahibi olurken sergiledikleri davranışların Weber'in pratik rasyonel davranış olarak adlandırdığı kavramı destekler nitelikte olup olmadığının anlaşılmasıdır.

ÜYT yoluyla çocuk sahibi olan bireylerin davranışlarının, Weber'in pratik rasyonel davranış kavramsallaştırması/ideal tipiyle ilişkilendirilmesinin nedeni bu ideal tipin, çalışmada yer alan katılımcıların hangi düşünce şekline uygun davranarak yargılanmaktan kaçındıklarının anlaşılmasına yardımcı olacağı fikridir. Bilindiği üzere Weber, anlamaya dayalı bir sosyoloji önermiştir ve birey davranışlarının anlaşılması için de toplumsal eylem ideal tipleri oluşturmuştur.

$\mathrm{Bu}$ çalışmada yer alan birey davranışlarının, duygularına veya geleneklerine bağlı davranışlar sergilemek suretiyle Weber'in irrasyonel eylem tipine uygun olmadığı rasyonel eylem tipine uygun olduğundan hareketle bir analoji kurulmak istenmiştir.

Bu amaçla bu makalede, Weber'in rasyonellik tipleri kısaca hatırlatılarak, yasaklanan ÜYT deneyimleri 1şığında bireylerin davranışlarının Weber'in tanımladığı pratik rasyonel davranış tipi ile ne kadar uyumlu olduğu anlaşılmak istenmiştir.

\section{YÖNTEM}

ÜYT süreçlerinde yer alan bireylerin rol yapma davranışlarının nedenleri ve sonuçlarının araştırıldığı bu çalışmada araştırmacının, 2017-2018 yılları arasında doktora tezi için bu süreçlerde yer alan Türklerle veya Türk ailelerin çocuklarını taşıyan Gürcü kadınlarla gerçekleştirdiği 12 görüşmenin ilgili bölümlerden yararlanılmıştır (Evsel, 2018). Burada ifadelerine yer verilecek kişiler, bu süreçlerde taşıyıcı annelik yapmış, bir taşıyıcı anne yoluyla çocuk sahibi olmuş veya yumurta donörlügü yapmış kadınlar ve eşlerinden 
oluşmaktadır. Bu görüşmeler 1 saat ila 3 saat arasında değişen yüz yüze derinlemesine mülakat şeklinde Türkiye, Gürcistan ve Kıbrıs’ta yaşayan bireylerle araştırmacının kendisi tarafından gerçekleştirilmiş, her biri yine araştırmacı tarafından deşifre edilmiş ve MaxQda Programı kullanılarak incelenmiştir. Görüşmeler, bir tanesi dışında ses kaydı alınmak suretiyle kayıt altına alınmıştır. İki Gürcü taşıyıcı anne ile yapılan görüşmelerde tercüman desteği alınmıştır. Onun dışında kalan görüşmeler Türklerle, Türkçe dilinde yapılmıştır. Katılımcıların 10’una kadın doğum uzmanları, embriyologlar, Yardımcı Üreme Merkezlerinde çalışan hemşireler aracılığıyla; ikisine ise kartopu örneklem üzerinden ulaşılmıştır. Makalede, katılımcıların doğrudan ifadelerine yer verilmiş olup, gerçek isimleri yerine takma isimler kullanılmıştır.

ÖYP (Öğretim Üyesi Yetiştirme Programı) dışında herhangi bir kurum veya kuruluş tarafından ilave maddi destek alınmayan bu çalışma için ODTÜ İnsan Araştırma Etik Kurulundan Etik Onay belgesi alınmıştır. $\mathrm{Bu}$ onay kapsamında katılımcıların her biri görüşme öncesinde bilgilendirilerek araştırmaya katılım onamları sağlanmıştır.

Kuramsal açıdan Weber'in rasyonalite kavramı ele alınarak, ÜYT deneyimlerinde ona uygun davranan bireyler davranışları, araştırmacının saha bulguları ile yeniden tartışılacaktır.

Aşağıdaki bölümde konuyu ele alan kısa bir literatür taraması yapılmıştır.

\section{ALANYAZIN TARAMASI}

Üreme sosyolojisi daha çok cinselliğin tarihi içerisinde ve beden sosyolojisinde temellenmektedir. Her iki alan da insanlığın tarihi ile birlikte şekillenmektedir. Habermas (2003, s. 73), yaşam dünyamızın bir bakıma “Aristotelesçi” biçimde yapılandığını vurgulamaktadır. Ona göre, organik ve inorganik doğa ayrımını üzerinde fazla düşünmeyerek bitkileri hayvanattan, hayvan aleminiyse akıl sahibi toplumsal insan doğasından ayırt ederiz. Bu kategorik sınıflandırma yapma nedenimizi ise "bizim dünyayla münasebette olma formlarımızdan doğan bakış açılarımız" belirlemektedir. Habermas'a (2003, s. 74) göre bu formlar, Aristoteles'in temel kavramlarından hareketle çözümlenebilir. 
Aristoteles'e (2017, s. 30) göre, canlılar ak1l ve bedenden meydana gelirler; burada ak1l yöneten, beden ise yönetilendir. Aristoteles'in (2017, s. 30) eserlerindeki köle tanımı ve açıklamalarının aslında Kant'ın (2005, s. 226) sonraları aydınlanma argümanını üzerinde temellendireceği vesayet konusunun köklerini oluşturduğu söylenebilir. Aristoteles (2017, s. 30) bu eserlerinde, hayvanların -kendilerinden akılca üstün olan- insanlar tarafindan yönetilmesinin onlar için daha güvenli bir yaşam sağlayacağından hareketle, bu ilişki biçimini insanlar toplulukları için de uygulamaktadır. Bu bağlamda der ki, “...nasıl ki bazı insanlardan sadece bedenlerini kullanarak çeşitli işler yapmaları dışında başka bir şey beklenemezse o insanlar da doğal olarak köledirler" (Aristoteles, 2017, s. 31). Hatta Aristoteles, dişi ve erkek arasında da birisinin yöneten diğerinin yönetilen olduğuna dair bir ilişki biçimi olduğunu da ileri sürer (2017, s. 31). Aristoteles'e göre, doğaya müdahale etmeksizin onu gözlemleyen kuramsal duruşun yanı sıra iki farklı duruş daha vardır (Habermas, 2003, s. 74):

...Üreten ve belli bir amaca yönelik edimde bulunan, böylece doğaya müdahale ederek araçlar kullanan ve malzeme tüketen öznenin teknik duruşu ile akı1la ya da törel olarak edimde bulunan, etkileşim ilişkileri içinde birbirleriyle karşılaşan kişilerin pratik duruşu.

Aristoteles'in bu rasyonel davranış açıklaması, sonraları Weber'in pratik-rasyonel davranışının temelini oluşturmuştur. Öyle ki Habermas (2003, s. 73) kitabında, hayvanlarını güdüp, tarlasını süren çiftçinin pratiklerini kuramsal duruş, hastalıkları teşhis edip hastalarını iyileştiren hekimin pratiklerini teknik duruş, bir popülasyondaki kalıtsal özellikleri kendi amaçları doğrultusunda yetiştiren ve geliştiren yetiştiricinin edimlerini pratik duruşa örnek olarak göstermiştir. Özellikle pratik duruşla ilgili tanım ve örnekler, Weber'in pratik-rasyonel davranışı yerleştirdiği kökenlere işaret etmektedir.

ÜYT süreçlerinde yer alan bireylerin sergiledikleri çoğu davranış, bu çalışmada pratik-rasyonel davranış kavramıyla ilişkilendirilmektedir. Bu amaçla, Weber'in (2012) literatüre yaptığı önemli katkılardan yalnızca rasyonellik ve pratik-rasyonellik ile ilgili olanlar dikkate alınmak suretiyle yararlanılmıştır. 
Weber'e (1950, s. 75) göre rasyonelleşme, aklın belirli bir eylemi bugün için mevcut bulunan boyutlarıyla, öncesini ve sonrasını da göz önünde bulundurarak kontrol etmesi, yönlendirmesi ve nihayete erdirmesi durumudur. Pratik-rasyonellik ise, amaç, araç ve değer-rasyonelliklerinin sistematik şekilde bütünleşmesidir. Bu açıdan Weber amaç-rasyonellik ile değer-rasyonellik şartlarının bir eylem veya kararda mevcut bulunmasını pratik-rasyonellik olarak ifade eder (Weber, Habermas'tan aktaran Çamlı, 2020, s. 18).

Diğer bir deyişle pratik-rasyonellik, bireyin ihtiyacını karşılamak üzere rasyonel amaç ya da amaçlar ortaya koyması; sonrasında bu amaç veya amaçları karşılayan en uygun, akılcı, verimli, etkin ve az maliyetli araç, yöntem ve uygulamaları araştırması ve kıyaslaması; beklentilerin gerçekleşip gerçekleşmeme ihtimallerine hazırlıklı olması ve ortaya çıkabilecek beklenmedik şartlara karşı stratejiler üretmesi; tüm bu eylem ve karar sürecinde kendi çıkarını, başarısını, faydasını da gözeterek dini ve ahlaki değerlere göre hareket etmesidir (Weber, 1950 s. 71). Parsons, sonraları Weber'den, geliştirdiği bu kavramı ödünç alarak onu daha ileriye götürecektir.

Bu çalışmada Weber'in yukarıda açıkladığı pratik-rasyonel davranışın ÜYT deneyimleri ile ilişkilendirilen örnekleri aşağıdaki gibi ele alınmıştır:

1. ÜYT süreçlerinde yer alan bireylerin ihtiyaçlarını karşılamak üzere, çocuk sahibi olmak veya başkalarını çocuk sahibi yapmak gibi rasyonel amaç ya da amaçlar ortaya koydukları;

2. Sonrasında bu amaçları karşılayan en uygun, akılcı, verimli, etkin ve az maliyetli araç, yöntem ve uygulamaları araştırdıkları ve kıyasladıkları, hatta bu kıyas sonucunda bu isteklerini gerçekleştirebilecekleri ÜYT leri buldukları ve bunun için Türkiye’ye en yakın ve makul ülkeler olan Gürcistan ve Kıbrıs'1 tercih ettikleri;

3. Beklentilerin gerçekleşip gerçekleşmeme ihtimallerine hazırlıklı oldukları ve ortaya çıkabilecek beklenmedik şartlara karşı stratejiler ürettikleri; tüm bu eylem ve karar süreçlerinde kendi 
çıkarlarını, başarılarını ve faydalarını gözeterek dini ve ahlaki değerlerine göre hareket ettikleri izlenmiştir.

Elbette Aristoteles'in, Weber'in ve başka birçok düşünürün ileri sürdüğü rasyonalizm açıklamaları bazı çağdaş düşünürlerce de eleştirilmekte, bireylerin bu davranışları daha farklı açılardan da yorumlanmaktadır.

Cinsellik ve üreme ile ilgili özellikle çağdaş yaklaşımların temelini oluşturan Cinselliğin Tarihi adlı kitabında Foucault (2007, s. 12), 17. yüzyıl ve 19. yüzyıl toplumlarını cinselliğe ve üremeye yaklaşımları açısından karşılaştırmakta ve Aristoteles'in temellerini oluşturduğu ve Victoria döneminin mührünü vurduğu bu yaklaşımları eleştirmektedir. Foucault'nun söz konusu rasyonalizm eleştirisi hala varlığını sürdürmektedir. Toplumda evlilikle kurulan ilişkilerin çocukları saygı görmektedir. Buna karşın, evlilik birliği dışındaki kişilerin üreme hücresi kullanılarak dünyaya getirilen çocuklar, genellikle yadırganmakta, "normal" karşılanmamaktadır.

Üreme ile ilgili günümüzde önemli yaklaşımlarda bulunan Franklin (2013: 154-155), akrabalıktan farklı olarak cinsellik ve üremenin "sadece biyolojik" olarak görüldüğünü ifade edip bu ikilinin gerçek mekanizmalarının henüz kuramsallaştırılmadığını çünkü bu açıklamalara gerek duyulmayacak kadar ortada olduklarının sanıldığını paylaşmaktadır. Oysa ona göre IVF'nin, üreme ile ilgili başarısızlıklarına rağmen, evlilikle ilgili ne kadar başarılı bir teknoloji olduğu, benzer şekilde üreme ile ilgili olanlardan bağımsız olarak toplumsal cinsiyet kimliği ve rollerinin üretilmesinde ne kadar yüksek başarılı bir teknoloji olduğu, hatta Franklin'in (Becker'den aktaran Franklin, 2013, s. 154) ileri sürdüğü gibi, uğraştırıcı bir kimlik üretimine, kimlik sonrası mücadelelere, veya bir sınıf kimliğinin yeniden üretiminin bir aracına neden olan bir teknoloji olup olmadığı gibi soruların tartışılması gerekmektedir. $\mathrm{Bu}$ soruların hepsi, IVF teknolojilerinin bebek yapmaya yardımcı rolünden ziyade toplumda anlamlar yüklenen, hatta bireyleri çocuk sahibi yapmaktan daha başarılı olduğu başka yönlerinin de, hatta bu diğer yönlerinin daha çok dikkate değer olduğuna işaret etmektedir. 
Bu makale bu noktada, yani üreme biyoteknolojisinin çocuk yapmaya yardımcı olma rolünün dışında, bu süreçlerde yer alan bireylerin davranışları üzerinde yarattığı etkilere odaklanmaktadır.

Burada hatırlanması gereken önemli bir diğer konu, üçüncü tarafları içeren bütün ÜYT’lerin (diğer bir deyişle, üçüncü kişilerden alınan yumurta, sperm ve embriyo donasyonunun ve taşıyıcı anneliğin) 2010 yılında Türkiye'de, yönetmelikle yasaklanmış olmasıdır. ${ }^{2}$ Zaman içerisinde bu yasak daha fazla genişletilmiş; sınırları, farklı hukuki yaptırım ve cezalarla daha belirgin hale getirilmiştir ${ }^{3}$. Türkiye gibi, vatandaşlarının üçüncü kişilerin dahil olduğu ÜYTleri kullanmasını yasaklayan başka ülkeler de vardır. Ancak Türkiye, bu uygulamaları vatandaşlarına ülke içinde ve dışında yasaklayan tek ülke olmuştur. Dolayısıyla, böylesi bir alanda saha araştırmaları yapmak zor olduğu kadar, literatür için büyük önem de arz etmektedir. Bu nedenle Türkiye'deki bu üreme yasağı ve bireylerin deneyimlerine 1şık tutan çalışmalar (Türkmendağ, 2012; Gürtin, 2012; Ungan Çalışkan, 2016; Mutlu, 2018) önem taşımaktadır.

Türkmendağ’’n (2012, s. 145) belirttiği gibi: “Türkiye hükümetinin, vatandaşlarının yurtdışında bile üreme hücresi arama ve almalarını yasaklaması onun Sınır Ötesi Üreme Bakımı (CBRC- Cross-Border Reproductive Care) hareketine karşı yasa çıkartan ilk ülke olmasını sağlamıştır.” Mutlu'nun (2018, s. 166) çalışmasında aktardığına göre hükümet, ulusal donasyon yasağını bir adım daha ileri götürerek ulus-ötesi bir boyut getiren bu düzenlemeyle artık sperm ve/veya yumurta donasyonu için yurtdışına hasta yönlendirmek, aracılık etmek ve (donör veya hasta olarak) bizzat gitmeyi yasaklamış; aksi yönde hareket eden kişi ve kurumların savcılığa bildirileceğini belirtmiştir.

${ }^{2}$ Resmî Gazete no 27513, 6 Mart 2010; 'Üremeye Yardımcı Tedavi Uygulamaları ve Üremeye Yardımcı Tedavi Merkezleri Hakkında Yönetmelik,' Elde edildiği tarih: 15.09.2018, ilgili link: http://www.resmigazete.gov.tr/eskiler/2010/03/20100306$\underline{10 . h t m}$

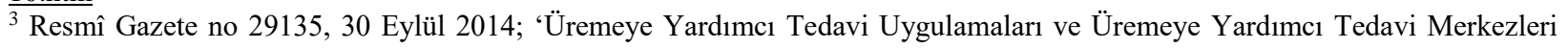
Hakkında Yönetmelik, $\quad$ Elde edildiği tarih: $15.09 .2018, \quad$ ilgili https://www.mevzuat.gov.tr/Metin.Aspx?MevzuatKod=7.5.20085\&MevzuatIliski=0\&sourceXmlSearch=\%C3\%9CREME

$\mathrm{SAD} / \mathrm{JSR}$

Özel Sayı 
Acaba bu yasak, zemini nereden almakta, meşruiyetini nereye dayandırmaktadır? Fukuyama (2003, s. 110, 111) bu soruya “din, insan genetik mühendisliğine en açık karşı çıkış zeminini oluşturur” cevabını verir. Yahudiler, Hıristiyanlar ve Müslümanların ortak geleneğine göre, insanın Tanrı'nın suretinde yaratıldığını hatırlatmakta ve bu cevabını aşağıdaki gibi temellendirmektedir:

İnsanın ve insan olmayanların yaratılışları arasında çok belirgin bir ayrım bulunur; yalnızca insanlar ahlaki seçim, özgür irade ve inanç yetilerine sahiptir. Bu yetiler onlara geri kalan hayvan yaratılışından daha yüksek bir ahlaki konum sağlar. Tanrı bu sonuçları elde etmek için doğa aracılığıyla hareket eder; dolayısıyla cinsel ilişki sonucunda çocuk sahibi olmak ve aile gibi doğal normların aksine davranış biçimleri, Tanrı iradesine karşı gelmek sayılır... Bu öncüller göz önüne alındığında, Katolik Kilisesi’nin ve muhafazakâr Protestan gruplarının doğum kontrolü, yapay dölleme, kürtaj, kök hücre araştırmaları, kopyalama ve genetik mühendisliğinin olası biçimleri de dahil olmak üzere biyomedikal teknolojiye bir bütün olarak güçlü bir tavır almaları şaşırtıcı değildir (Fukuyama, 2003, s. 110, 111).

Türkiye toplumunun daha çok Müslüman nüfusundan oluştuğu bilinmektedir. Ancak böylesi bir yasağg, Fukuyama’nın yukarıda ifade ettiği gibi, dinle doğrudan ilişkilendirmek ne kadar doğru olur? Bu soruyu makalelerinde ele alan Gürtin, Inhorn ve Tremayne (2015, s. 3149) Sünni Arap dünyası, Şii İran ve Seküler Türkiye'yi karşılaştırmış ve sonuçta bu ülkelerde, ÜYT'ye yönelik tek ve basit bir "İ̀slami” cevabın olmadığında karar kılmışlardır. Bu durumda en fazla belirleyici olan faktör ise Sünni ve Şii otoritelerin varlığ1 olmuştur. Sünni otoriteler, kısırlık tedavilerinde üçüncü kişileri kapsayan tüm uygulamaları yasaklarken, Şii otoriteler diğerine kıyasla ÜYT ile ilgili izinlerde ve verilen fetvalarda daha farklı politikaları destekleyebilmektedir. Gürtin vd.'nin (2015, s. 3150) vurguladığı diğer önemli bir nokta, dinin yeni teknolojiler ve onların toplumsal etkileri üzerine kişisel ve kültürel kanaatlerin geliştirilmesinde çok önemli bir faktör olmasının yanı sıra, tek başına belirleyici faktör olmadığıdır: diğer bir deyişle, din ve kültür etkileşimi göz ardı edilmemelidir. 
Gürtin vd.'nin (2015) bulgularıyla paralel bir şekilde söylenebilir ki, söz konusu yasağın toplum bireylerini üçüncü kişilerin yer aldığı yardımcı üremeye başvurmaktan alıkoyması mümkün olmamıştır. Doğal yollarla çocuk sahibi olamayan bireylerin, yurt dışında veya içinde bu süreçlerde yer alarak çocuk sahibi olmayı/veya sağlıklı bireylerin başkalarının çocuk sahibi olmasını sağlamayı başardıkları anlaşılmaktadır. Bürokrasiler ve toplum baskısı el ele vererek, bu bireyleri toplumdaki saygınlıklarını kaybetmemeleri için hem ÜYT'ler yoluyla çocuk sahibi olmaya, hem de çeşitli yaptırımlardan ve bürokrasiden kaçınmak isteyen bireyleri farklı biçimlerde rol yapmaya itmiştir.

Yasalar ve bürokrasi, bireylerin üreme davranışlarını ve organlarını belirli kurallara göre kullanmalarını öngörmüştür. Ancak, yine daha çok toplumsal yapılar ve içerisinde doğulan toplum tarafindan şekillendirilen çocuk sahibi olma isteği baskın gelmekte; bireyleri bu kuralların dışında hareket etmeye ve bu kurallara uygun olmayan davranışlarını ise çeşitli şekillerde saklamaya, diğer bir deyişle stratejik davranmaya itmektedir.

Bu nedenle bu makalede, ÜYT süreçlerinde farklı rollerde yer alan bireylerin pratik-rasyonel davranışlar sergileyerek bürokrasi ve otorite ile baş etme biçimleri ele alınmaktadır. Burada, yasal olarak belirlenen alanla ilgili düşünceler ve katılımcıların yasal olmayan deneyimleri paylaşılmış ve otoritenin ortaya koyduğu yasağın meşruluğu ÜYT uygulamaları özelinde yeniden sorgulanmıştır.

\section{BULGULAR}

Yukarıda belirtildiği gibi, bu bölümde ÜYT’lere başvuran ancak Türkiye'de yasaklandığı için otoritenin belirlediği bürokratik ve toplumsal kurallara uyuyormuş gibi görünen bireyin üreme süreçlerinde başvurdukları pratik-rasyonel davranışları ele alınmaktadır. ÜYT yoluyla çocuk sahibi olan bireyler ve bu süreçlerde yer alan üçüncü kişiler, daha çok cezalandırılmaktan ve toplumsal çevreleri tarafından yargılanmaktan kaçınmak amacıyla bu deneyimlerini saklama eğilimi göstermektedirler. Özellikle kadınlar ve sürecin içinde birlikte yer aldıkları aileleri bu baskıdan kaçmak için çeşitli yollara başvurabilmektedirler. 
Aşağıda, ÜYT süreçlerinde farklı paydaşlar olarak yer alan taşıyıcı anneler, taşıyıcı anne yoluyla çocuk sahibi olan kişiler, yumurta donörleri ve taşıyıcı anne yoluyla çocuk sahibi olan kişilerle ilgili veriler ayrı ayrı ele alınarak tartışılmıştır.

\section{1. ÜUT Süreçlerinde Taşıyıcı Anneler ve Pratik-Rasyonel Davranış}

$\mathrm{Bu}$ çalışmadaki anlatımlara ve ilgili sosyal medya paylaşımlarına göre, taşıyıcı anneler özellikle hamileliklerinin son dönemlerinde, komşu ve tanıdıklarına içinde bulundukları durumu açıklamak zorunda kalmamak için başka bir şehre, yakın arkadaşlarına, başka bir eve veya çocuğu verecekleri ailenin yanına taşınmak durumunda kalmaktadırlar.

Burada ifadesine ilk olarak yer verilecek olan kişi, Ayten, Adana'da eşi ve çocukları ile birlikte yaşayan bir taşıyıcı annedir. Ayten'in konu ile ilgili olarak belirtmiş olduğu ifadelerinden, onun toplumsal baskı ve utanmadan, ayrımcılık ve toplumsal baskıdan kaçınmak için pratik-rasyonel davranış kalıbına uygun hareket ettiği görülmektedir. Ayten'in ve eşinin evlerinin tadilatı, üç çocuğunun bakımı, eşinin işsizlikle geçen dönemi nedeniyle yaşamlarını sürdürebilmek için para kazanması gerekiyordu. Bu amaçla, eşinin ve çocuklarının yanında yapabileceği onun için en kolay ve hızlı para kazanma yolu taşıyıcı annelik yapmaktan geçiyordu. Evli olması, gebelik süreci için bir avantaj bile sağlayacaktı. Çevresine karşı, gebeliğin evlilik birliği içinde oluştuğunu söyleyebilirdi. Hatta bu düşüncesini "bu işi bekar kadınlar nasıl yapıyor, hiç aklım almıyor. Benim en azından başımda kocam var..” şeklinde ifade etmiştir. Yine de Ayten'in hamilelik sonunda bebeği ile ilgili gelecek olan sorulardan kaçınabilmesi için, evinden bir süre taşınması gerekmiştir.

Ayten'in ifadeleri sonucunda, ÜYT süreçlerinde, taşıyıcı annelik deneyimi yaşayan bireylerin sadece hamileliğin gerçekleştiği ilk süreç ile ilgili değil; aynı zamanda anne karnının belirginleştiği, yani gebeliğin görünür olduğu, hamileliğin ilerleyen dönemlerinde de önemli ve ilk dönemlerine göre daha farklı kaygılar da yaşayabildiği anlaşılmaktadır. Ayten bu süreci aşağıdaki gibi deneyimlemiştir: 
Çok iyi anlaştık. Eşyalı ev tuttu, böyle bir dairede birlikte kaldık. 4 ay sonra bu evden gittim ben. Hepimiz gittik eşim, çocuklar falan, biz şey dedik. Bir iş var diye gittik biz, kapıcılık işi gibi. Komşulara evet. öyle gittik biz. Zaten benim [karnım] 4 aydan sonra çıkıyor. Türk Milleti sonuçta yani, herkes bir eleştiri söylüyor.

Görüldüğü gibi Ayten ve ailesi çevrelerine karşı yeni bir iş bulmuş gibi davranmış, ücret karş1llğ 1 gerçekleştirdikleri bu hamileliği "başka bir binada kapıcılık yapma" rolü altında tamamlayabilmişlerdir. Ancak gerçekte, ailesiyle ve çocuğu alacak olan kadınla birlikte başka bir dairede kalmış, doğum gerçekleşene kadar hamileliğini yakınlarından gizleyebilmiştir.

Yine de Ayten her şeyin ortaya çıkmasından korktuğunu belirtmiştir. Ancak bu korku kendisinden ziyade, çocuğu taşıdığı kadın adına hissettiği bir korkudur. Taşıyıcı annenin de sosyal annenin de toplumsal çevrelerine karşı rol yapmaları zor süreçler yaşamalarına neden olmaktadır. Hayatlarına dair aldıkları bu önemli kararı uygulamaları, konu ile ilgili yasaklar nedeniyle daha fazla zorlaşmaktadır. Taşıyıcı anneler, hamileliğin ilerleyen süreçlerinde karınlarını çevrelerinden saklamaya çalışırlarken, sosyal anneler ise bunun tam aksine çevrelerine karşı hamileymiş gibi görünmeye gayret etmektedir. Her ikisi de aynı sürecin farklı rollerini üstlenmiş kadınlar oldukları için bu rollere uygun görünmeye çabalamakta, çevrelerini buna uygun şekilde kandırmaktadırlar. Ayten bu durumu şöyle ifade etmiştir:

Valla endişem ne yani? Hesaplamadığım bir şey. Bir de her şey ortaya çıkmasın sonuçta. O aile için de önemli çünkü eşinden başka kimse bilmiyor. Herkes onu çocuğu zannediyor sonuçta.

Anlaşılacağı üzere, burada rol yapan sadece Ayten değildir. Ayten'in bedenini kullanarak çocuk sahibi olan kadın da çevresine karşı rol yapmaktadır. Ayten'in anlatımına göre, kadın Almanya'da eşiyle yaşamaktadır. Hamile ve ailesinin yanında doğum yapacakmış gibi Türkiye’ye gelmiştir. Ayten, bu sosyal annenin saygınlığı adına da endişe duyduğunu ifade etmiştir. Ona göre, sosyal anne, kuma baskısı ile ÜYT 
süreçlerine başvurmaya ve pratik-rasyonel davranışlar sergilemeye itilmiştir. Ayten'in kelimeleriyle başından geçen bu süreç aşağıdaki gibi gelişmiştir:

Boşanmak değil kuma. Yani bir de Doğulu olduklanı için Antepli oldukları için. Almanya'da yaşıyorlar, Berlin’de. Ailesi bu tarafta. Ailesi Türkiye'de yaşıyor. Kendisi kocasıyla Almanya'da. Zaten akrabalardı, teyzesinden, eşiyle yani. Doğuluları bilirsin, çocuk olmayınca hemen kumaya başvururlar ya o yüzden. Kötü bir şey yok ki bu taşıyıcılık olsun, bir aileyi.. yani ben maddi yönden o da manevi yönden zengin ediyorum ben. İki aile de mutlu oluyor sonuçta yani amacına ulaştıktan sonra. Ha Türkiye'de yasaklıyorlar ya sonuçta yani.

Ayten'in yukarıda yer verdiğgi “Kötü bir şey yok ki bu taşıyıcılık olsun, bir aileyi.. yani ben maddi yönden o da manevi yönden zengin ediyorum ben. İki aile de mutlu oluyor sonuçta yani amacına ulaştıktan sonra.” ifadesi pratik-rasyonel davranış tanımının hatırlanması gereken bir ifade olmuştur. Pratik-rasyonellik bireylerin "tüm bu eylem ve karar sürecinde kendi çıkarını, başarısını, faydasını da gözeterek dini ve ahlaki değerlere göre hareket etmesidir (Weber, 1950 s. 71).” Ayten'in iki tarafın da yapılan bu işten çıkarının olduğu ve verdiğini düşündüğü manevi huzur, pratik-rasyonel davranışın tanımına uygun betimlemeler içermektedir.

Taşıyıcı annelerin içinde yer aldıkları ÜYT süreçlerinde oldukları/hissettikleri gibi davranamadıkları bir konunun da emzirme ile ilgili olduğu anlaşılmıştır. Türk taşıyıcı annelerden bazılarının doğurdukları bebekleri emzirmeyi istedikleri ancak çocuğu verdikleri aileler istemeyince emziremedikleri, Gürcülerin ise, emzirmek istemedikleri halde aileler istediği için emzirmek durumunda kalabildikleri görülmüştür.

Ayten, aşağıda belirttiği gibi, hastaneye doğuma giderken emzirmemesi konusunda tembihlenmiş ve her iki kadın da Türkiye'de gerçekleştirilen doğum sonrasında hastanede yine pratik-rasyonel davranış sergilemek durumunda kalmışlardır: 
Onu da demişti zaten bayan bana hastaneye giderken. Emzirmesen daha iyi olur dedi, çünkü hazır mama verecekti. Ne bileyim emzirmemi istemedi. Ben de tamam dedim yani. Ben isteseydim hemşirenin yanında emzirebilirdim ama aile böyle dediği için hatta bayan teşekkür etti, sağol dedi emzirmediğin için dedi. Sonra hazır mama getirmişti zaten yanında, hemşire görmeden veriyordu. Hemşire geldi mi biberonu saklıyordu.

Türklerin bebeğini taşıyan bir Gürcü taşıyıcı anne olan Elene, emzirme konusundaki endişesini bebeğe bağlanmak istememesiyle açıklamıştır:

Hiç düşünmek istemiyorum. Sonuçta vermem gerekir. Hiç o yüzden kendimi telkin ediyorum düşünmeyeyim diye. Çocuğu da görmesem daha iyi olur, bağlanmak istemem.

Doğum sürecinde yine taşıyıcı anneler, doğurdukları bebeğin yasal anneleri olmadıkları için yukarıdaki örneklerde görüldüğü gibi, doğum sonrasında emzirme ile ilgili olarak veya hastaneye başvurduklarında kimlik beyan ederken bazı sorunlar yaşayabilmekte, özellikle bu hususlar yasalarla belirlenmediği zaman kişisel inisiyatiflerle aşılmaya çalışılmaktadır. Diğer bir deyişle, zaman zaman yargılanmaktan, zaman zaman ise bağlanmaktan kaçınmakta; hem de kendileri için maksimum fayda elde edecek şekilde davranmaktadırlar.

Ayten'in belirttiği gibi, Türkiye'de gerçekleştirilen bu gibi doğumlarda taşıyıcı anne, kendi nüfus bilgilerini saklayabilmektedir:

Doğumu ailenin kimliğiyle yaptık. O yüzden doktora ekstradan para ödediler. Yani doktor da tehlikeye attı kendini. Yani mesleğinden olur öyle birşey duyulursa. Çünkü yasal değil. Gizli işler. Normal gittim özeline, bayanın kimliğiyle herşey yapıldı yani. Özel hastanede. Zaten doğum adına olduğu için sorun olmuyor zaten. Bir tek aile, götürmekte zorlandı işte Almanya'ya çocuğu. Hani, Türkiye'de doğduğu için, yurtdışına götürmek biraz sorun oldu. [Başka bir ilde] beklediler bir ay falan ancak öyle götürebildiler. Direk götürülmüyor zaten. 
Ayten'in yukarıda açıkladığı durum, soy bağını yanıltmayı içerdiği bilindiği için, yasalar önünde suç teşkil etmektedir. Bu bilgi aslında, ÜYT sürecinin içerisinde yer alan, doktor ve sağlık çalışanları dahil herkes için risk oluşturan bir konudur.

Ancak Ungan Çalışkan (2016, s. 504) makalesinde taşıyıc1 anneliğin, çocuk doğmadan önce soy bağ1 değiştirildiği durumlar için cezai durum oluşturmadığını tartışmaktadır. Ona göre gerek taşıyıcı annenin gerekse gönüllü annenin ve/veya babanın doğum sertifikasını tağyir etmesi halinde soybağını değiştirme ve gizleme suçu işlemiş olacağı düşünülebilir. Öte yandan ceza hukuku doktrininde yalnızca sağ doğan çocukların nüfusa kaydolması nedeniyle soybağının tağyirinin söz konusu olabilmesi için çocuğun sağ doğmuş olması gerektiği, bu nedenle embriyonun soybağının değiştirilmesi hallerinde suçun işlenmiş sayılamayacağı; yani üremeye yardımcı tedavi esnasında embriyonun karı-koca anne-baba dışında üçüncü şahısların üreme hücreleri kullanılarak oluşturulması durumunda TCK'nın 321. maddesinin uygulama alanı bulamayacağı görüşü vardır (Yenerer Çakmut’tan aktaran Ungan Çalışkan, 2016, s. 504, 505).

Ancak pratik-rasyonel davranış gereği Ayten de Elene de dahil oldukları süreci kurallarına göre tamamlamış, pratik-rasyonel; diğer bir deyişle menfaatinlerine uygun ve ilkeli ölçütler, verdikleri sözler dahilinde gebeliklerini sorunsuz tamamlayarak bebekleri ailelerine bu hukuki şartlar altında teslim etmişlerdir. Görüldügü gibi, yasadışı ortamlarda bile pratik-rasyonel eylem optimum faydayı hesaplayabilmekte ve bu amaca uygun olarak ortaya çıkabilmektedir.

\subsection{Taşıyıcı Anne Yoluyla Çocuk Sahibi Olma ve Pratik-Rasyonel Davranış}

Taşıyıcı anne yoluyla çocuk sahibi olan annelerin, özellikle de çevreleri tarafindan bebek bekledikleri biliniyorsa, karınlarının belirginleşip belirginleşmediği sorgulanan ve paylaşılan bir konu olagelmektedir. $\mathrm{Bu}$ nedenle bu süreçte yer alan anneler de, toplumsal çevrelerini bebeklerinin gelişine, yaşadıkları yerden uzaklaşarak hazırlamaktadırlar. 
Fatma, Karadeniz Bölgesi'nde yaşayan ve taşıyıcı anne yoluyla çocuk sahibi olan bir annedir. Görüşme esnasında Fatma, taşıyıcı annenin çocuğuna hamile kaldığını öğrenmiş, gebeliğin tamamlanmasını beklemekte idi. Onun da bu süreçte, Ayten'in çocuk sahibi yaptığı anne gibi, çevresine karşı rol oynamak durumunda kaldığını görmekteyiz. Karadeniz Bölgesi’nin de çocuk sahibi olma ve aile ilişkileri konularında Türkiye'nin çoğu bölgesi gibi muhafazakâr olduğu bilinmektedir. Fatma, bu özel durumunu sadece annesi ile paylaşabilmiş. Geri kalan çevresine ve özellikle eşinin ailesine karşı rol yapacağını belirtmiştir.

Fatma’nın kendi anlatımıyla bu ÜYT süreci aşağıdaki gibi planlanmıştır:

Yok, hiçbir aşamayı hiçbiri bilmiyor. Sadece annem biliyor. O da zaten yaşı hani sadece bana destek oluyor işte, 'kızım üzülme hani şey yapma'.. Böyle hani beni anlasa oturup konuşabileceğim hani o kadar şey yok. Aramızda çok yaş farkı var annemle. Ama hiç kimseye anlatmadım yani eşimin aile tarafında hiç anlatmadım. Yani başka çarem yok. Son aylarda uzaklaşacağım yani son mesela 6 aylıktan sonra uzaklaşacağım. Hani kendim o aya kadar, biraz topluyum yani hani. Göbek kısmım da hani üstten biraz çıkıntılı hani öyle bir yapım var hani. Balık etliyim. Ama hani son aylara doğru artık uzaklaşacağım hani başka bir şansım yok. Gürcistan'a [gideceğim], yakın zaten orda ablam var akrabalar var, abim var hani öyle düşünüyorum eğer olursa.

Görüldüğü gibi, Fatma da fiziksel özelliklerini avantaja çevirerek, rolünü yukarıdaki senaryoya göre oynamayı ve çevresi tarafından utandırılmaktan veya küçük düşürülmekten, acınmaktan kaçınmayı hedeflemektedir. Onun için çocuk taşıyan kadın, Gürcü bir kadındı ve Gürcistan'da yaşamaktaydı. O nedenle, çocuğunun doğum tarihi yaklaştıkça Fatma, Gürcistan'a yakın olan akrabalarının yanında kalmayı, orada doğum yapmış gibi çocuğunu Gürcistan'dan alıp dönmeyi planlamıştır. Hedeflerine uygun, stratejik çözümler geliştirmiş, ihtimalleri hesaplamıştır. 
Fatma'nın da bu süreçlerde yer alan diğer bireyler gibi üreme süreçleri ile ilgili olarak arkadaş veya akrabalarına gerçeğe dair bir şey anlatmadığı anlaşılmaktadır. Sadece eşleri ve çok yakın akrabaları detayları bilmektedir. Karadeniz'de yaşamanın getirdiği coğrafi avantajla birlikte Fatma, doğum sürecini diğer bireylerden daha iyi planlayabilmiştir. Gürcistan, Batum'daki yardımcı üreme merkezlerini tercih eden Türk aileler için özellikle Doğu Karadeniz'de yaşamak stratejik bir öneme sahip olmaktadır. Yukarıda belirttiği gibi Fatma, doğum zamanı yaklaşınca Batum'a yakın bir şehirdeki kardeşinde veya yakın akrabalarında kalacaktır. Diğer bir deyişle, üreme yöntemi ile ilgili olarak doğru bilgileri akrabalarıyla, ancak gerekirse paylaşacaktır.

Fatma dışında, taşıyıcı anne yoluyla çocuk sahibi olacak olan Eda ve Serkan'la olan görüşmede Serkan daha çok, bürokrasi ile ilgili olarak endişeler duyduğunu "Sınırdan çocuğu çıkartırken sorun olur mu diye korkuyorum sadece ben biraz" sözleriyle belirtmiştir. Görüldüğü gibi, taşıyıcı anne yoluyla çocuk sahibi olan aileler bürokratik ve hukuki engellerle ilgili endişeler yaşadıklarını ifade etmişlerdir. Acaba bu endişelere kapılmak ve yasa dışı yollara başvurmak yerine, evlatlık çocuk başvurusunda bulunmayı düşünmediler mı?

Birincisi, taşıyıcı anne Ayten'in belirttiği gibi, bazı kadınlar hangi nedenle olursa olsun, kendi çocuklarını doğuramazlarsa kuma bazıları ise boşanma ile karşı karşıya kalabilmektedir. Evlatlık edinme, kişilerin içinde bulunduğu sosyal çevrelerine bunu kabullendirebildikleri veya olası tepkilere kayıtsız kalabildikleri durumlarda hayata geçebilmektedir. ÜYT uygulamaları ve taşıyıcı annelik veya donasyon yoluyla çocuk sahibi olan aileler, çocuk sahibi olduklarını genellikle sosyal çevrelerinden saklayabilmektedirler.

İkincisi, bireylerin evlat edinme başvurularında sıklıkla karşılaştıkları bürokratik engeller, onların ÜYTlere yönelmesine neden olabilmektedir.

Üçüncü olarak ise, bireylerin mümkünse kendi çocuklarına sahip olmak, değilse de en azından yeni doğmuş bir bebek sahibi olmak istemeleri onları ÜYT süreçleri ile tanıştırmaktadır. Örneğin, daha önce evlatlık 
başvurusu da yaptıklarını bildiren Ali, bu başvurularında da bürokratik engellerle karşılaştıklarını ve büyük bir çocuktan ziyade yeni doğmuş bir bebek istediklerini aşağıdaki gibi anlatmıştır:

Esirgeme kurumuna gidiyorsunuz, yaşınız 40 oldu çocuk alamazsınız bilmem ne. 40’1 geçtikten sonra 41 oldunuz mesela 1 yaşında alabiliyorsunuz. 42 oldunuz, 2 yaşında alabiliyorsunuz. Öyle yasal.. Tabi alabiliyorsunuz ama biz de.. tabi biliyorsunuz insan $0 \mathrm{~km}$ istiyor herşeyi, çocuğu amiyane tabirle.

Ali’nin yukarıda bahsettiği, evlatlık çocuk edinme başvurularında yaş ile ilgili bürokratik engele yönelik son zamanlarda bazı iyileştirmeler yapıldığı bilinmektedir. Ancak bu ve başvuru sonrasında uzun süre beklemek gibi bürokratik engellerin, bireyleri uzun bir süre, evlatlık çocuk başvurusu yapma fikrinden uzaklaştırdığı bilinmektedir. Burada ÜYT uygulamaları yoluyla çocuk sahibi olan ailelerin Özbay'ın (1999) çalışmasında belirttiği gibi evlatlık edinme yönelimi içinde olmadığı ya da bu yönelimlerinin başarısız olduğu düşünülebilir.

\section{3. ÜYT Süreçlerinde Yumurta Donörü Olma ve Pratik-Rasyonel Davranış}

Herhangi bir nedenle çocuk sahibi olmak için yumurta üretemeyen kadınlar, yumurta donasyonu almaya başvurmaktadırlar. Yumurta donörleri, yumurtaları anestezi altında toplanmadan önce yumurtalıklarını uyarmak ve daha çok sayıda ve büyüklükte yumurta oluşumuna yardımcı olmak için hormon iğneleri kullanmak durumundadırlar.

Bu çalışma kapsamında görüşülen Sevgi adlı katılımcı, Kıbrıs’ta lisans eğitimi alan bir öğrenci ve düzenli bir yumurta donörüdür. $\mathrm{O}$ da ailesinin olası tepkilerinden kaçınmak için rol yapma davranışı içine girmek durumunda kaldığını bildiren bir katılımcı olmuştur. Onun için bu nedenle ailesinden uzakta, Kıbrıs'ta eğitim alıyor olmak bir avantaj olmuştur. Bu sayede ne ailesine durumu açıklamak ne de onların yargı ve müdahalelerinden kaçınmak için sürekli rol yapmak durumunda kalmaktadır. 
Sevgi, eğer ailesiyle yaşıyor olsaydı yumurta donörlüğünü yapmasının imkânsız olduğunu ifade etmiştir. Yine de deneyimlediği bir anı üzerinden ailesinin yanında bu süreci nasıl atlatabildiğini paylaşmıştır. Bu iğnelere henüz birkaç gün önce başlamışken, ailesi tatil için yanına geldiği zaman, iğneleri aracında saklayıp uygulayarak, risk alması gerektiğini belirtmiştir.

Sevgi bu süreci aşağıdaki gibi ifade etmiştir:

Ha Türkiye'de yapmazdım. Ama burada mesela bayrama denk geldi bir önceki. Bizimkiler de buradayd1, herkes buradayd1, bütün ailem buradayd1. Ve ben yine yaptım. Ama bu büyük bir cesaret. Arabada buz şeylerinin içine koyuyordum, kolilerin içine koyuyordum iğneleri. Yapılıyor ya. Ama yapmazdım. Öyle bir şeye onların yanında başlamazdım. Öyle bir şey, bunların yanında yaptım ama onlar gidiciydi. Yani misafir olarak düşündüğüm için. Yoksa burada yaşasa yani hepsi yapa.. yapmazdım ya.. Çünkü o riski alamam.

Aslında Sevgi de Fatma da birbirine benzer şekilde coğrafi yakınlık veya uzaklıktan dolayı üçüncü kişileri kapsayan ÜYT süreçlerinde farklı rollerde yer alırken coğrafi yakınlık ve uzaklığın avantajlarını kullanmışlardır. Sevgi de Fatma da, daha çok ailesinin yanında farklı davranışlar sergilemek durumunda iken, onlardan uzakta iken özgür hissetmekte ve böyle bir kaygı duymamaktadır.

Hatta sürekli rol yapamayacağını düşündüğü için Sevgi, eğitimini tamamladıktan sonra artık yumurta donasyonu yapmayacağını da belirtmiştir. Diğer bir deyişle, uzakta olmak Sevgi’yi bürokratik ve toplumsal baskılarla strateji savaşında avantajlı duruma getirmiştir.

Ancak, uzaklık bazı pratikler için dezavantaj da getirebilmektedir. Zeynep için durum böyle olmuştur. Zeynep, rahmine yerleştirdiklerinin bir embryo değil de, kendisine başvuran çifte ait sperm olmasından şüphelenen bir taşıyıcı annedir. Zeynep'in endişeleri aşağıdaki gibidir: 
Ya o benim kendi çocuğumsa? Ya bana söylemeden rahmime sperm enjekte etmişlerse? Bunu affedemem. O benim çocuğumsa, bir de onu taşıdıysam, annesiyim ben onun. Onu almam gerekir, başkasına emanet edemem. Bunu nasıl anlayabilirim? Annelik testi yaptırmak istiyorum. Ailenin haberi olmamalı. Çocuk okula, en azından kreşe gidene kadar beklemeliyim. Saç telini alabilsem yeter. İzlerini buldum zaten, isimlerini biliyordum. Çocuğun saç telinden benim çocuğum olup olmadığı anlaşılır. Eğer benim çocuğumsa mahkemeye de veremem. Onu kaçıracağım. Umarım benim değildir. Ona bakacak durumum yok, ama bir şekilde halledebilirim. Zaten birkaç sene sonra ortaya çıkar, bir işim olabilir o zamana kadar.

Aileye böyle bir endişem olduğunu, ve saç örneğini almak istediğimi söylersem vermez, bir de polise şikayet ederler. Ama artık dayanamıyorum. Uyuyamıyorum, içim içimi yiyiyor. Bunu hissettim, o benim çocuğum olmalı. Öyle garip davrandılar ki, bunu hissettim. Bir gün bunu anlayacağım. Herşey gün yüzüne çıkacak. Onların sahtekarlığı ortaya çıkacak.

Zeynep yukarıda görüldüğü gibi, içinde yer aldığı yasadışı sürecin cezasını vicdanen çok yüksek bedellerle ödemektedir. Yasalarla belirlenmemiş bu alanın özellikle Türkiye'de gerçekleştirilen hiçbir anı kayıt altına alınmamakta, kuralları sözleşmelerle belirlenmemektedir. Dolayısıyla, şifahen yapılan bu anlaşmalarda kurallara uyulup uyulmadığı genellikle ispatlanamamakta, ispatlansa bile bireyler yasadışı bir süreçte yer aldıkları için haklarını arayamamaktadır.

$\mathrm{Bu}$ örnekte, diğerlerinden farklı olarak pratik-rasyonel davranışın Zeynep'in içinde bulunduğu olumsuz ÜYT koşullarına ve süreçlerine uygun olarak geliştiği görülmektedir. Zeynep, bir şekilde çocuğun kendine ait olduğunu ispatlarsa, onu kaçırmayı düşünmektedir. Aslında bu kurguda da Zeynep stratejik ve amaçlarına uygun hareket etmekte; bu amaçlarını, inandığı kişisel değerleri ile paralel şekilde gerçekleştirmeyi istemektedir. Amaçlarına, değer ve inançlarına uygun, stratejik bir davranış yönelimi olduğu açıkça görülmektedir. 


\subsection{Yumurta Donasyonu Yoluyla Çocuk Sahibi OIma ve Pratik-Rasyonel Davranış}

ÜYT süreçlerinde yer alan ve en az rol yapma davranışı sergilemek durumunda kalan grup muhtemelen yumurta donasyonu yoluyla çocuk sahibi olan anneler olmaktadır. Bu grupta, daha çok Kıbrıs veya Gürcistan'da, genellikle -eğer eşlerinin spermleri çocuğun oluşumu için yeterli düzey ve kalitede iseeşlerinin spermi ve yumurta donörünün yumurtası laboratuvar ortamında birleştirilerek tüp bebek yapılması sağlanmakta ve uygun süre içinde bu bebekler onlara hayatları boyunca eşlik edecek olan annelerinin (sosyal ve biyolojik anne) rahimlerine yerleştirilmektedir.

Dolayısıyla bu grupta yer alan anneler, hamilelik ve doğum süreçleri sonrasında, yaşadıkları bu ÜYT süreçlerini unutmaya ve çocuklarını kendi çocukları gibi benimsemeye çok daha yatkın olmaktadır. Bu grupta yer alan annelerden birisi Hale' dir. Hale, ağır bir kanser tedavisi gördüğü için yumurtaları elverişsiz hale gelmiş; defalarca gerçekleştirdikleri tüp bebek girişimleri olumlu sonuç vermemiştir.

Hale, bir zamanlar içinde bulunduğu bu durumu aşağıdaki gibi ifade etmiştir:

Ben unuttum aslında. Hani onu diyorum ya işte aslında. Unutuyorsun yani. Unuttum derken hani işte bir, bir dokunaklı bir şey gibi düşündüğüm için hani kendim doğurdum kendim emziriyorum, benim çocuklarım. O hissiyat çok farklı. Hani o konuyu tekrar konuşuyor olmak da ya insanlara bir yararı olacaksa mesela ben destek de olup konuşabilirim de birisi bunu düşünüyorsa mesela işte bana fikir sormak istese. Ben beyan ederim fikrimi. O konuyu unutmak derken tamamen kapamak şeklinde değil. Ama hani insan böyle bir şey yaşadığını unutuyor çocuklarla olduktan sonra. Nasıl diyeyim, hani doğumu da unutuyorsunuz bir yerden sonra o acıları, sıkıntıları. Hani o sıkıntıları, acıları, insan beyni öyle herhalde sıkıntıları acıları atıyor, güzel şeylere konsantre olmayı tercih ediyor. Öyle oluyor yani çocuklar olunca.

Hale'nin paylaştığı bu anlatı, yaşadığı süreci hayatında nasıl konumlandırdığıyla ilgili olarak önem taşımaktadır. Donasyon almış olduğunu unutmak istediğini, kendi doğurup emzirdiği için çocuklarını tam 
anlamıyla benimsediğini ifade etmektedir. Ancak Nurgül, kendisine yapılan donasyon ve tüp bebek işlemleri anestezi altında gerçekleştirildiği için, başarısız olan bu işlemlere yönelik şüphe içinde olduğunu aşağıdaki gibi belirtmiştir:

Ha tabi şey, şöyle.. Zaten hani bu yapıl.. yumurtayı koymadı belki. Öyle şeyler de okudum ben internette. Kıbrıs'ta. Yumurta nakli.. Zaten bir hafta sonra hamilelik testi yapıyorsunuz hani.. Ben mesela iki embryo yerleştirdiklerini ultrasonda gördüm. Pit atıldı. Ama onun embryo olduğunu ben bilmiyorum. Bişe attılar sonuçta, su da olabilir. Bilmiyorum ki...

Yumurta donasyonu alma yoluyla çocuk sahibi olma, ÜYT süreçleri içinde sosyal, ekonomik ve psikolojik anlamda en kolay yönetilebilir ve rol yapma davranışı gerektirmeyen, aileler için sadece gizlilikle atlatılması gereken bir hamilelik başlangıcını içeren bir süreç olarak anlaşılmıştır. Ancak süreç içinde ailelerin yoğun bir güvensizlik içinde oldukları, zaman zaman tüp bebek merkezlerine olan güvenlerini sorguladıkları; ancak bu endişelerini çocuk sahibi olma umudu taşıdıkları için saklamak durumunda kaldıkları, yine mutlu olmak ve çevrelerini mutlu etmek adına, amaçlarına uygun ve stratejik davrandıkları görülmektedir.

\section{5. ÜYTlere Başvurmadan Çocuk Sahibi Olma ve Pratik-Rasyonel Davranış}

Bundan önceki bölümlerde bireylerin ÜYT süreçlerinde yasal yaptırımlar ve çevresel-toplumsal baskılardan kaçınmak için içinde bulundukları pratik-rasyonel davranışlar, ilgili örnekler üzerinden incelenmiştir. Bu bölümde ise, ÜYT süreçlerine başvurmadan çocuk sahibi olmada sergilendiği anlaşılan bazı pratik-rasyonel davranışlara kısaca değinilmektedir. Türkiye'de bir kadın doğum uzmanı ve embriyolog olan Veli, kendisine farklı zamanlarda çocuklarının olmaması nedeniyle başvuran hastalarının hangi ilişkiler üzerinden çocuk sahibi olmayı denediklerini aşağıdaki gibi özetlemiştir:

Bir de biz bazı şeyleri yasaklıyoruz ne oluyor? Örneğin kadının çocuğu olmuyor, kız kardeşinin oluyor. Kız kardeşine diyor ki bir tane doğur bana ver diyor, bu en masumu. Kendi kocasıyla onun 
kendi kızkardeşi ilişkiye giriyor. Bu ikinci kademe. Üçüncü kademe adamın spermi yok, bilem ne. Bu arada bir falan olmuyor bizim ülkemizde. Yani köylerde çocuk sahibi olamamak çok büyük bir yük ve bunu aileler kendi usulleriyle çözmeye çalışıorlar. Ee, gidiyor bir başka erkekle beraber olmasına karısının izin veriyor. Yani bu hikâyeleri ben, 200000 hasta ile görüştüm, neler dinlediğimi anlatamam sana. Burda biz onların önüne yarattığımız sosyal engellerle onun sperm donasyonunu o biçim usullerle yapmasına meydan veriyoruz. Sperm donasyonu Türkiye'de var ve yaygın. Hem de nasıl yaygın.. Eşle dostla, kardeşle, bilmem neyle cinsel ilişkiye giren insanlar var Türkiye'de. Ben doğum hastanesinde çalıştım. Orda kadın doğumda çalışsan neler neler dinlersin. Yani benim bildiklerim bunlar.

Veli tarafindan "Çocuk sahibi olamamanın bireylere getirdiği yük” sonucu bireylerin ÜYT'nin yasak, pahalı, uzak olması veya bilinmemesi nedeniyle başvurdukları çözümler (!) anlatılmıştır. Aslında bütün bu kişisel paylaşımlar, üçüncü kişilerin yer aldığı ÜYT uygulamalarının “muhafazakâr bir toplum olma” veya “soy bağını bozma-yanıltma” gerekçeleriyle yasaklanmasının başarılı bir politika olmaktan ziyade, başarısız olduğunu göstermektedir.

Bu bölümde, bulgularla desteklenmeye çalışlan konu, üçüncü kişileri içeren ÜYT süreçlerinin hangi tarafında yer alırsa alsın, bireylerin çevrelerine karşı nasıl pratik-rasyonel davranış içinde bulunduklarını ortaya koymaktır. Burada yer alan örnekler, münferit gibi görünse de, farklı, gizli ve riskli bir grubun deneyimleri ile ilgili olarak literatüre katkı sunması ve hatta alan ile ilgili yeni politikalar üretilmesi açısından önem taşımaktadır. 


\section{SONUÇ VE TARTIŞMA}

Bu çalışmada bulgular, Türkiye'de yaşayan ve üreme süreçlerinde üçüncü kişilerin bedenleri ve üreme hücrelerine başvuran bireyler ile ilgili gerçekleştirilmiş nitel bir araştırmaya dayanmaktadır. İki ayrı problem ayrışarak ortaya çıkmaktadır. Bunlar: Türkiye'de ÜYTler üzerinden yaratılan pratik-rasyonel davranış şekli ile Türkiye'deki ÜYT yasağının meşruiyet problemidir.

Araştırmanın literatüre en önemli katkıları, 1. ÜYT süreçlerinde yer alan bireylerin stratejik, gizli, rolyapmacı davranışlarının Weber'in pratik-rasyonel davranış kavramı ile olan uyumunun, 2. ÜYTlerin yasadışı değil, onu yasaklayan otoritenin meşru kabul edilmeyip ona uygun davranışlar sergilenmemesinin, ortaya çıkan bu pratik-rasyonel davranışlar üzerinden keşfedilmesidir. Katılımcıların özellikle bu çalışmada yer alan davranışlarının pratik rasyonel davranış tipine uygun olduğu anlaşılmakta bu tespit ve araştırma katılımcılarının davranışlarını söz konusu analoji içinde anlamamızı kolaylaştırmak suretiyle literatüre katkı sağlamaktadır.

Bu çalışmada yer alan katılımcıların, Weber'in pratik-rasyonel eylemine uygun davrandıkları görülmüştür. Weber'e göre bu tür davranış içinde olan bireyler faaliyetlerinde maksimum fayda elde edeceği akılcı hedefler belirler, hedefine ulaşmak için etkin yöntemleri seçer, bu süreçte dini ve ahlaki ilkelere göre davranır. Sadece kendi menfaatini değil, karşısındakinin ya da içinde yaşadığı toplumun genel menfaatini de dikkate alır (Weber, 1950: 75). Zira Çamlı'nın (2020, s. 19) belirttiği gibi, “pratik-rasyonellik dinamiklerinin özünde insanın günlük hayatını kolaylaştırma, hayatı ve çevreyi daha yaşanabilir kılma, fayda ve kârı optimum ahlak noktasına çıkarma, toplumsal rızayı ve konsensüsü tesis etme, özgür ve mutlu bireyler yetiştirme, sosyal refahı arttırma, adilane ve barışçıl bir toplum inşa etme gibi idealler yatıyorsa," ÜYT uygulamalarına başvuran bireylerin de bu davranışa uygun hareket ettikleri söylenebilir. Türkiye'de çocuk sahibi olamayan bireyler yasadışı da olsa ÜYTlere başvurarak ve pratik-rasyonel davranışlar sergileyerek: 
1. Boşanma, kuma gibi yaptırımlardan kaçınarak günlük hayatlarını kolaylaştırmakta,

2. Kendilerinin ve ailelerinin saygınlıklarını korumakta,

3. Kendilerinin, çocuklarının ve ailelerinin toplum baskısı olmadan, özgür ve mutlu yaşamalarını sağlamakta,

4. Dolayısıyla ahlaki, dini, kültürel ve toplumsal değerleriyle çelişmeyen çünkü her tarafin çıkar sağladığı bir "çocuk sahibi olma" veya "çocuk sahibi etme” ediminde bulunabilmektedirler.

Toplumun ve yasaların üreme konusunda uyguladığı baskının, bireyler üzerinde caydırıcı etki oluşturmadığı görülmüştür. Aksine bu yasak, bireyleri rol yapma ve stratejik davranma davranışlarını gerçekleştirmek suretiyle cezadan ve yargılanmaktan kaçınarak ÜYT süreçlerinde yer alma yoluna itmektedir.

Diğer bir deyişle, bireyler ona uygun davranmayarak aslında, otoritenin meşruluğunu kabul etmemektedir.

Bir davranışın, teknolojinin veya temel ihtiyacın yasaklanması, onun gerçekleştirilmeyeceği anlamına gelmemektedir. Hatta bu gibi örneklerin gerçekleşme biçimleri onu, göze alınan riskleri ve uğrunda verilen tavizler bakımından bilimsel araştırma ve incelemeler için zor; ancak çok daha değerli hale getirmektedir. Konunun önemi ve araştırmanın daha önce bahsedilen sınırlılıkları nedeniyle, benzer araştırmaların daha geniş ÜYT süreçlerinde yer alan katılımcılar ile gerçekleştirilmesi, desteklenmesi ve Türkiye'ye ait daha geniş bir literatür oluşturulması gerekmektedir. Bu çalışma özelinde Weber'in pratik-rasyonel davranış tanımına odaklanılmış, meşruiyet/otorite türleri konu dışına çıkmamak adına göz ardı edilmiştir. Ancak, Türkiye'nin hangi otorite/meşruiyet türü ile yönetildiği ve bireylerin ÜYT bağlamında bu otorite türü ile ilişkisi de başka çalışmalarda ele alınabilir.

Kant'ın (2005, s. 230) Aydınlanma Nedir' i sonlandırırken ifade ettiği düşüncenin burada anılması faydalı olacaktır: “...Son olarak bu insanların hürriyeti kullanabilme yeteneğine sahip olması siyasi iradenin 
ilkelerini etkiler, ki siyasi irade, artık makineden fazlası olan insanlara, onurlarına saygı göstererek davranmayı kendi lehine bulur."

Anlaşıldığ gibi, aydınlanma için bireysel aydınlanma bunun için de siyasi iradenin bireysel onura ve düşünceye saygı göstermesi şarttır. Bunlardan herhangi birisinin eksik olması durumunda, bireyler karar vermek için de kararlarını uygulamak için de daima başkalarına tabi olmak durumunda kalacaklardır. Bu konu özgürlükler, akıl ve meşruiyetin yeniden sorgulanmasını gerektirmektedir. 


\section{SUMMARY}

Developments in the field of biomedicine directly affect the social lives of people who experienced Assisted Reproductive Technologies (ARTs). It is known that in Turkey, using the third parties' bodies and gametes in the In Vitro Fertilization processes of couples is banned and punished via regulations in the field of ARTs. However, that punishment and ban do not make families disclaim having a baby via these technologies including third parties. Rather, they started to make it in a more insecure and secret way afterwards.

For this reason, it is claimed and supported by the field results in this paper that Turkish citizens were forced to apply for some ways in order to avoid any kind of punishment such as social exclusion and legal enforcements. This study focuses on the practical-rationality concept of Weber, which was adopted in this study for people avoiding social pressure and humiliation in not being able to have a child or in requiring other people's bodies for this aim.

The results of face-to-face interviews of the researcher with surrogate mothers, oocyte donors, couples who had their children via surrogacy and embryologists are used in this study. In other words, this paper aims at understanding if ARTs and restrictions have social pressure on surrogate mothers and oocyte donors, who are mainly worried if their roles reveal in the end, and families that have their children via these ways; and finally understanding the strategies which these people appeal to avoid from humiliation in Turkey.

In this paper, the statements of the participants were given directly as quotations. These statements were discussed and interpreted in the context of rationalism and specifically, the practical-rationality concept of Weber. Finally, the possibility of living private and reproductive lives under no pressure for individuals in Turkey is discussed under the light of research findings. 


\section{KAYNAKÇA}

Aristoteles (2017). Politika: Bütün Yapıtları-3, F. Akderin (Çev.), İstanbul: Say.

Çamlı, A. Y. (2020). Yeni Bir Toplum Kuram Dinamiği: Pratik Rasyonellik, Kocatepe İIBF Dergisi, 22(1), 14-27.

Evsel, G. (2018). Human Rights Domain for Reproductive Biotechnology: A Qualitative Study on Turkish Case. (Yayınlanmamış Doktora Tezi). Orta Doğu Teknik Üniversitesi Sosyal Bilimler Enstitüsü Bilim ve Teknoloji Politikası Çalışmaları EABD.

Foucault, M. (2001). Power. R. Hurley (Çev.), New York: The New.

Foucault, M. (2007). Cinselliğin Tarihi, İstanbul: Ayrıntı.

Franklin, S. (2013). Biological Relatives: IVF, Stem Cells and the Future of Kinship, Duke University.

Fukuyama, F. (2003). İnsan Ötesi Geleceğimiz: Biyoteknoloji Devriminin Sonuçları, A. Fromm (Çev.), Ankara: ODTÜ.

Gürtin, Z. B. (2012). Practitioners as Interface Agents between the Local and the Global: The Localization of IVF in Turkey, Academia.

Gürtin, Z. B., Inhorn, M. C. ve Tremayne, S. (2015). Islam and Assisted Reproduction in the Middle East: Comparing the Sunni Arap World, Shia Iran and Secular Turkey, Book Chapter 165 in The Changing World Religion Map, Springer Science and Business Media Dordrecht, 3137-3153.

Habermas, J. (2003). Insan Doğasının Geleceği, K. H. Ökten (Çev.). İstanbul: Everest.

Kant, I. (2005). Aydınlanma Nedir? Liberal Düşünce. A. Yayla (Çev.), 20(38-39), 225-230.

Malthus, T. (1998). An Essay on the Principle of Population, Electronic Scholarly Publishing Project. URL: http://www.esp.org/books/malthus/population/malthus.pdf

Mutlu, B. (2018). Gizleyerek Aile Olmak: Yurtdışında Yasaklı Biyoteknolojilerle Çare Arayışları. Toplum ve Bilim, 144, 161-194. 
Özbay, F. (1999). Türkiye'de Evlatlı Kurumu: Köle mi Evlat mı? (Çevrimiçi) URL: https://www.academia.edu/1156044/T\%C3\%9CRK\%C4\%B0YEDE_EVLATLIK_KURUMU_K \%C3\%96LE_M\%C4\%B0_EVLAT_MI

Türkmendağ, İ. (2012). Home and Away: The Turkish Ban on Donor Conception. Law, Innovation and Technology, 4: 2, 144-164.

Ungan Çalışkan, H. (2016). Bırakınız Taşısınlar: Taşıyıcı Anneliğe Güncel Bakış, MÜHF-HAD, 22(1).

Üremeye Yardımcı Tedavi Uygulamaları ve Üremeye Yardımcı Tedavi Merkezleri hakkında Yönetmelik, Resmî Gazete no 27513, 6 Mart $2010 . \quad$ URL: https://www.resmigazete.gov.tr/eskiler/2010/03/20100306-10.htm

Üremeye Yardımcı Tedavi Uygulamaları ve Üremeye Yardımcı Tedavi Merkezleri hakkında Yönetmelik, Resmî Gazete no 29135, 30 Eylül 2014. URL: https://www.mevzuat.gov.tr/mevzuat?MevzuatNo=20085\&MevzuatTur=7\&MevzuatTertip=5

Weber, M. (1950). The Protestant Ethic and the Spirit of Capitalism, Third Impression. Tr. T. Parsons, New York: Charles Scripner's Son.

Weber, M. (2012). Sosyolojinin Temel Kavramları, İstanbul: Yarın. 